\title{
Sighing for a Soldier: Jane Austen and Military Pride and Prejudice
}

\author{
TIM FULFORD
}

\section{$\int_{\text {INCE the } 1970 \text {, critical inquiry into }}$ \\ Jane Austen's novels has come to focus} upon their relationship to the social and political issues of a nation that, in the years during which Austen was writing, was almost continually at war with revolutionary France. Critics have extensively discussed Austen's attitudes toward radicalism and Jacobinism, as well as her references to West Indian slavery, the issue around which many radicals united. ${ }^{1}$ Yet it is only in the last few years that they have begun a detailed scrutiny of her part in some of the most urgent debates of the period. These debates, which figure more explicitly in her books than does the abolitionist campaign, concerned the proper role and conduct of the armed forces and of the men who served in them. In Persuasion (1818), as Anne K. Mellor and Brian Southam have demonstrated, Austen contributed to a national discussion about the degree of social status and political authority that might be allowed to an expanded class of professional gen-

Nineteenth-Century Literature, Vol. 57, No. 2, pp. 153-1 78. ISSN: $0891-9356$.

(C) 2002 by The Regents of the University of California/Society. All rights reserved.

Send requests for permission to reprint to: Rights and Permissions, University of California

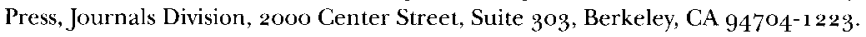

1 On Jacobinism, see Warren Roberts, Jane Austen and the French Revolution (New York: St. Martin's Press, 1979); on slavery, see Edward W. Said, Culture and Imperialism (New York: Alfred A. Knopf, 1993 ). 
tlemen-naval officers. ${ }^{2}$ In Pride and Prejudice (1813), I shall suggest, Austen entered a similar debate about the role of army (specifically militia) officers in a manner that aligned her-at least on this issue - with the public rhetoric not of her Tory neighbors but of radical Whigs. ${ }^{3}$

The debate about the militia grew in stridency over thirtyfive years, with particular climaxes in the late 1790 s, when Austen was drafting what was to become Pride and Prejudice, and again from 1811 to 1812 , when she was revising it. A long and complex debate, it requires a detailed elucidation before a critique of the novel's contribution to it can be made. Accordingly, I begin by focusing on the debate itself before turning, in the second half of this essay, to consider Pride and Prejudice in depth.

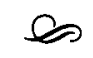

In the British countryside of the late eighteenth century the most striking new thing was an officer's coat. The military was in residence for the first time, and its dress was anything but uniform. The red, blue, and green coats shone in a dazzling variety, identifying the wearers not as individuals but as members of different regiments. ${ }^{4}$ What splashed regimental color into the countryside was a situation that was to last almost throughout Jane Austen's writing career-war with France. In 1757 , and again in 1778 (when the French joined the Ameri-

2 See Mellor, Mothers of the Nation: Women's Political Writing in England, r $780-1830$ (Bloomington: Indiana Univ. Press, 200o); and Southam, Jane Austen and the Navy (London and New York: Hambledon and London, 2000).

${ }^{3}$ In Jane Austen and the War of Ideas (Oxford: Clarendon Press, 1975), pp. 161-299, Marilyn Butler traces the continuation of $179^{\circ}$ anti-Jacobinism into the nineteenth century, but she does not always place sufficient emphasis on the realignment of politics that, beginning at the outset of the Regency, was to lead to the Reform Act of 1832 . Like Gary Kelly in Women, Writing, and Revolution, I790-I 827 (Oxford: Clarendon Press, 1993), p. 182, I take a different view than Butler of the "war of ideas" in which Austen participated. In Jane Austen and Representations of Regency England (London and New York: Routledge, 1994), Roger Sales gives a more nuanced picture of Austen's relationship to the shifting political positions of the Regency.

4 The older term for military dress, "regimentals" (the first OED citation is from the London Magazine in 1742), conveys this sense; the newer term "uniform" (the first OED citation is from 1748) suggests even more strongly that the new coats made the soldiers appear identical. I am grateful to Debbie Lee for her advice on terminology here and throughout this essay. 
can colonies in war with Britain), a worried ministry began to raise a militia intended to defend the country from invasion. Landowners as great as Mr. Darcy sprang to the fore-the Duke of Devonshire, for instance, left London to organize and train the militia of his locality. So did other great aristocrats, and their brightly colored uniforms became fashion items.

Despite the alarm about a possible French invasion, the militia impressed the public more as a spectacle than as a fighting force. According to a field officer writing to the London Chronicle, the Duke of Devonshire found himself in camp at Coxheath (Kent) together with fifteen thousand men and the "flower of the Nobility." Over three miles long, Coxheath was soon a magnet for sightseers both common and aristocratic. A coach service had to be set up to let Londoners satisfy their curiosity to view what the Chronicle calls "one of the most striking military spectacles ever exhibited in this country." 5 The spectators saw brightly dressed men, commanded by dukes, exercising (for some of the time), but they also saw the kind of aristocratic self-indulgence that was normally hidden behind the doors of the great houses. The Duke of Devonshire had several marquees pitched, one acting as his personal kitchen, another as his servants' hall, and another as his entertaining rooms. ${ }^{6}$ In the camp at Winchester, Oriental rugs, "festoon-curtains, ... chintz sophas," and silver candlesticks made the camp a place of opulence. ${ }^{7}$ Yet as the Morning Post reported, the most glamorous spectacle was the uniforms, the "regimentals," especially when the Duchess of Devonshire redesigned them to clothe herself and the other ladies whom she formed into a female auxiliary corps: "Her Grace the Duchess of Devonshire appears every day at the head of the beauteous Amazons on Coxheath, who are all dressed en militaire; in the regimentals that distinguish the several corps in which their Lords, \&c. serve, and charms

5 [Anon.], "Extract of a Letter from a Field Officer, dated Coxheath Camp, Kent, June 10," London Chronicle, 13-16 June 1778, p. $57^{\circ}$.

${ }^{6}$ See Gillian Russell, The Theatres of War: Performance, Politics and Society $I_{793-1815}$ (Oxford: Clarendon, 1995), p. 38 . My discussion of camp culture is indebted to Russell throughout.

${ }^{7}$ See [anon.], "Extract of a Letter from an Auctioneer, dated Winchester, July 9," Morning Chronicle, 16 July 1778 , p. [4]. 
every beholder with their beauty and affability." with admiring the men's uniforms, the Duchess and other society ladies played at being soldiers, to the admiration of the sightseers. The camp seemed, as Gillian Russell has noted, a theater of "social and sexual interchange"-or, in the words of the anonymous novel Coxheath-Camp (1779), "a masquerade [that] levels all distinction." 9

All this cross-dressed fashion parade was a long way removed from the horrors-and the glories - of battle, and it seemed still more so when it emerged that the noblemen and noblewomen at Coxheath had played at other games besides soldiering. They had undressed as well as dressed up: "the officers," wrote the Morning Chronicle, "were in the practice of conducting their ladies, pro nocte, secretly into their marquees." 10 The Duke of Devonshire dallied with Lady Jersey while his wife paraded, Lady Melbourne became pregnant by Lord Egremont, and - in a scandal that fascinated the press - Lady Derby left her husband and children to live with the Duke of Dorset. The militia was making love, not war. As the heroine in Coxheath-Camp put it, "General Officers and Cadets, Duchesses and Demoiselles, are alike exposed to the snares of beauty, are alike susceptible to the tender passion." 11 The militia's reputation, after these scandals, would be more about the risks it posed to English ladies' virtue than the threat it made to Frenchmen's lives.

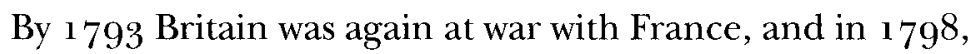
1803 , and 1809 , the nation was doing badly enough to face a more severe invasion threat. As Napoleon's fleet waited across the channel, the local militias, by this time swollen to three hundred thousand men under training per year, marched back and forth, camped, and danced at assemblies. For the inhabitants of English villages - especially in the southeast - the militia was, if not overpaid, definitely oversexed and over here. Still, the militia offered new glamour: only recently could soldiers wear their bright uniforms off duty, and only now were they spread across

8 "Foreign Intelligence," Morning Post, 18 July 1778 , p. [2].

9 See Russell, Theatres of War, p. 44; and Coxheath-Camp: A Novel in a Series of Letters by a Lady (1779), quoted in Theatres of War, p. 39 .

10 "Camp at Cox-Heath Intelligence," Morning Chronicle, 18 July $177^{8}$, p. [4].

${ }^{11}$ Coxheath-Camp, quoted in Russell, Theatres of War, p. 39- 
the country. The traditional English fear of a standing army had dissolved in the face of the French menace, and soldiers were now visible across the land as never before. Of course, this gave them a social mobility enjoyed by very few in eighteenthcentury England up to that point.

Like Mr. Wickham in Pride and Prejudice, a soldier posted away from his home district was free from those who knew him and his reputation. His very identity was changed: he was now an officer by title, and his previous self and his social status were covered by his gaudy regimental dress. But his dress and rank might well have been earned not by experience on the battlefield or parade ground but by influence, and the shiny uniforms masked a variety of characters and origins. Men got commissions in the local militias without needing ever to have owned a residence in the area ${ }^{12}$ - thus they could acquire social status regardless of merit or their reputation among those who knew their worth. It was, perhaps, the corrupting effect of this unearned social status that Jane Austen feared in her brother Henry. In 1796 he tried to obtain an adjutancy in the Oxfordshire regiment, and when he was unsuccessful he tried again in the 86th. In January 1796 Austen wrote to her sister Cassandra: "I heartily hope that he will, as usual, be disappointed in this scheme." 13 It was possibly the dangers that soldiering posed to the character (and the finances), rather than those it posed to the health, that she had in mind.

As contemporary satires suggested, the reputation of Britain's soldiers-as Napoleon loomed and as Jane Austen sketched out the work later to be published as Pride and Prejudice-was not high. It was the navy, not the army, that was having success in battle, despite the vast increase in the army's size (it grew from thirteen thousand men at the outbreak of war to two hundred thousand in 1807 ). But Britons had traditionally

12 This was true for men below the rank of captain, at least, like Wickham. Above this rank, a local property qualification was applied.

${ }^{13}$ Jane Austen, letter to Cassandra Austen, 9 January [1 796], in Jane Austen's Letters to Her Sister Cassandra and Others, ed. R. W. Chapman, 2d ed. (New York: Oxford Univ. Press, 1952), p. 3 (hereafter cited in the text as Letters). I should point out that if the cause of Austen's concern was the fear that Henry would be corrupted, then it was not only soldiering but other professions - including his failed venture into banking - that posed a threat. 
been suspicious of a large standing army: the Militia Act had provoked riots when it first passed in 1757 , and in 1808 there was opposition in parliament to Castlereagh's bill, which proposed to conscript the militia by ballot from the population at large and to place it under martial law when on duty. To liberal and radical Members of Parliament, the militia threatened to become a means by which an unrepresentative ministry could oppress the people - a threat that was carried out in 1812 , when the militia was used to quell Luddite protesters. Rather than helping to fight Napoleon, the militia seemed to many observers to be turning Britain into a military state, one symbolized by the new barracks in which soldiers were kept separate from their countrymen. By the end of the Napoleonic War no less than 155 barracks had been built all over the kingdom, despite protests in press and parliament. Something of the public unease they engendered can be seen in Keats's 1817 letter from the Isle of Wight: "On the road from Cowes to Newport I saw some extensive Barracks which disgusted me extremely with Government for placing such a Nest of Debauchery in so beautiful a place - I asked a man on the Coach about this - and he said that the people had been spoiled-In the room where I slept at Newport I found this on the Window 'O Isle spoilt by the Milatary." ${ }^{14}$ Clearly, soldiers in uniform, whether in barracks or village, put many Britons in mind of the risk of sexual corruption as well as political despotism.

For much of the Napoleonic period, soldiers appeared to be as incompetent in battle as they were dangerous in barracks. Corruption seemed to spread from the top down, and the army seemed dogged by aristocratic self-indulgence just when Britain wanted heroes to prove its power and manliness against the French. In the Anti-Jacobin in July 1798 George Canning called for a return to "manlier virtues, such as nerv'd / Our fathers' breasts." ${ }^{15}$ But the nation did not find a great warrior among its

14 John Keats, letter to J. H. Reynolds, $17-18$ April 1817 , in The Letters of John Keats, ${ }_{1} 814-1821$, ed. Hyder Edward Rollins, 2 vols. (Cambridge, Mass.: Harvard Univ. Press, 1958 ), I, 131-32. I am grateful to Nicholas Roe for alerting me to these remarks.

${ }^{15}$ George Canning, "New Morality," in George Canning and John Hookham Frere, Poetry of the Anti-Jacobin (1799; rpt. Oxford and New York: Woodstock Books, 1991), p. $140 ;$ Il. $454-55$. 
princes. The Duke of York commanded troops in the French Netherlands in 1799, but he attracted ridicule for marching back and forth, losing soldiers without ever coming into a decisive battle: "O, the grand old Duke o' York, / He had ten thousand men; / He marched them up the hill my boys, / Then marched them down again!" 16 This now-famous nursery rhyme was just one of the satires mocking York as an ineffectual soldier. In the broadside "The Duke of York's New March" he appeared as an absurd parody of a chivalric warrior:

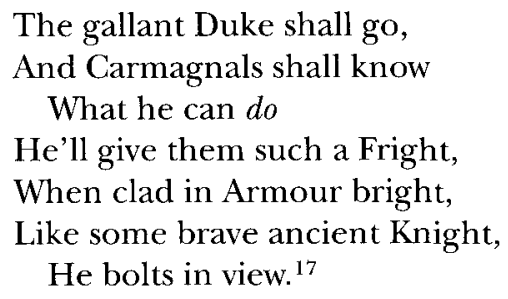

While the nation found knightly pretensions in the soldier princes and dukes, it also found sexual and financial corruption. In 1808 a great scandal broke upon Regency Britain, and the Duke of York, by now Commander-in-Chief of the army, was at its center. York's mistress, the longtime courtesan Anna Clarke, had been accepting bribes from army officers seeking promotion: to supplement the inadequate allowance that her royal lover gave her, she accepted cash, in return for which the Duke arranged rapid advancement for the officer concerned. It was also alleged that, as well as sterling, she accepted sexual favors from the more eligible soldiers. The anonymous author of Military Promotions; or, The Duke and his Dulcinea. A Satirical Poem (1809) imagined events thus:

$$
\begin{aligned}
& \text { "My Dear",-_said Proserpine one day } \\
& \text { Whilst with the Duke in am'rous play, } \\
& \text { "Let me a favour ask;" } \\
& \text { "Whate'er it is," replied the Duke, }
\end{aligned}
$$

16 "Duke o' York," in Mother Goose's Book of Nursery Rhymes and Songs, rev. ed. (London: J. M. Dent and Sons, 1931), p. 67.

17 "The Duke of York's New March," by "Peter Pension, Esq. Poet Laureat Extraordinary." Broadside, n.d., "sold by R. Lee, at the Trke of LiberTy, No. 2 St Ann's Court, Dean Street, Soho." 
Charm'd with her fascinating look

"To please,-—be mine the task."

"No,-_'tis not such a mighty thing,

'Tis a Commission from the King,"

The Dulcinea cried:

"Tis only to oblige a friend,

And well you know, I recommend

None whom I have not tried." 18

When the scandal broke, questions in the House of Commons brought about a full-scale pamphlet war and press campaign. A motion of censure was brought against the Duke as Commander-in-Chief, and sufficient MPs-Tory as well as Whig-condemned him for his resignation to become unavoidable. He was reappointed as early as 1811 , however, scandalizing commentators and public alike. Journalists such as Coleridge and Southey were most shocked by the conjunction of three things: aristocratic sexual immorality, financial corruption, and the army on whose strength the fight against Napoleon depended.

The York affair reveals that the sexual mores of the nobility were now a major issue in wartime politics. Many feared that their governors' "libidinous desire" (Military Promotions, p. 13) would leave the strength of the army sapped by female wiles, thus leaving the nation vulnerable to French invasion. Redcoats, it seemed, were too busy indulging their mistresses to be an effective fighting force, and York's conduct suggested that the officers were more concerned with enjoying the women impressed by their splendid uniforms than they were with beating Napoleon. The Duke's immoral and unchivalrous behavior discredited the army as an institution, just when it was most necessary to demonstrate Britain's superiority to its republican and revolutionary enemy across the channel. Redcoats seemed vain and craven, especially since the York scandal followed a military debacle: in late 1808 , at the Convention of Cintra, the generals fighting the French in Spain and Portugal surrendered their advantage and let Napoleon's army escape.

${ }^{18}$ Military Promotions; or, The Duke and his Dulcinea. A Satirical Poem (London: printed for the author, 1809 ), p. 3 . 
Austen did not comment directly on the York affair or the Convention of Cintra, but her letters indicate that she both felt horror at the killing of soldiers in battle and, at the same time, maintained an ironic distance from the war. Thus on 31 May 1811 (in the year of York's reinstatement) she wrote to Cassandra about the Battle of Albuera, in which the British took heavy casualties: "How horrible it is to have so many people killed!-And what a blessing that one cares for none of them!" (Letters, p. 286). Austen had said as much before, in 1809 , when the York scandal was at its height. On 30 January 1809 she wrote to Cassandra, after General Sir John Moore and many troops had died heroically at Corunna: "I wish Sir John had united something of the Christian with the Hero in his death.Thank Heaven! we have had no one to care for particularly among the Troops" (Letters, pp. 261-62). As Warren Roberts has shown, there is a self-protective sardonic humor in these comments that should not be equated with lack of compassion: because Austen can imagine how terrible it would be to lose a loved one, she is glad that she is not suffering personally (and of course having two brothers in the navy, she lived with that prospect constantly). ${ }^{19}$ But there is also a hint of criticism, not unrelated to what the army, in the years of the Duke of York scandal, symbolized. Moore had died a brave death but not a Christian one-he had not prayed, or acknowledged his sins and the suffering of his men, on his deathbed. Soldiers, it seemed, displayed little humility or compassion, and the Cintra Convention-when Moore had died trying to protect his troops after his fellow generals had let Napoleon's defeated army escape to fight another day-only seemed to confirm this view. In Wordsworth's verdict, the generals had cast shame on both the army and the nation:

If our Generals had been men capable of taking the measure of their real strength, either as existing in their own army, or in those principles of liberty and justice which they were commissioned to defend, they must of necessity [have rejected the peace terms offered by the French]; - if they had been men of common sagacity for business, they must have acted in this man-

19 See Roberts, Jane Austen and the French Revolution, p. 92. 
ner; - nay, if they had been upon a level with an ordinary bargainmaker in a fair or a market, they could not have acted otherwise.Strange that they should so far forget the nature of their calling! They were soldiers, and their business was to fight. Sir Arthur Wellesley had fought, and gallantly; it was not becoming his high situation, or that of his successors, to treat, that is, to beat down, to chaffer, or on their part to propose: it does not become any general at the head of a victorious army to do so. ${ }^{20}$

It is significant that in his comment Wordsworth accuses the generals not just of forgetting their duty in a cowardly way, but also of being incompetent as "men of business." Comparing them unfavorably to middle-class and laboring-class tradesmen, Wordsworth implies that their failure stems from their aristocratic rank. Command of the army was traditionally the prerogative of the nobility, but now, Wordsworth implies, the noblemen are too naive and unprofessional, too unschooled in the world of affairs, to be fit for their task. The aristocracy was coming to seem-to conservatives as well as radicals-too selfindulgent to be trusted to conduct the nation's interests.

The Duke of York's reappointment in 1811 reinforced this impression. Coleridge, in a piece that was suppressed from the Courier, wrote that reappointing York was "a bold indecent measure" and "a national insult," timed as it was to coincide with the good news of victory at Albuera. ${ }^{21}$ It was an insult because it showed that the self-interest of the princes and their ministers dominated policy - they favored themselves and made others dependent on them, monopolizing patronage. The army would again be commanded by a man who had promoted officers on the basis of how much they were prepared to pay his mistress. Successful and tried generals, like Moore, would be overlooked as the Duke promoted those who favored him with money or

${ }^{20}$ Wordsworth, "Concerning the Convention of Cintra" (1809), in The Prose Works of William Wordsworth, ed. W. J. B. Owen and Jane Worthington Smyser, 3 vols. (Oxford: Clarendon Press, 1974), I, 257.

21 Coleridge, "The Duke of York I" (1811), in Essays on His Times in "The Morning Post" and "The Courier," ed. David V. Erdman, 3 vols., vols. 1-3 of The Collected Works of Samuel Taylor Coleridge (London: Routledge/Princeton: Princeton Univ. Press, 1978), III, 221 . The essay was withdrawn from publication, supposedly for political reasons (see Erdman's headnote, "Suppressed and Rejected Essays on the Duke of York," in Essays on His Times, III, 220-21). 
flattery. Thus the perverted system, which ignored professional competence and rewarded princely and noble vanity, would continue-the very system that had left the army in the hands of the incompetent generals at Cintra.

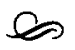

There is some question of how much we can read Austen in the light of British attitudes toward the military in this period. After all, she had little to say about foreign wars and Westminster politics, of which she had no direct experience. But as a number of scholars have shown, political and social debates lie just below the surface of Austen's work, and she alludes to them in brief but knowing references. ${ }^{22}$ Tracing these allusions gives us a changed picture of her work: no longer does it appear cut off from the great issues of the day, but instead is seen to deal with the way these issues flew from and back to the local level. Austen, that is to say, is a historical novelist who concerns herself not with battles and bills but with the contexts of those battles and bills, away from the public arena, in the country as a whole.

Austen, like Wollstonecraft and Mary Robinson, turned her acute intelligence toward understanding the social causes and effects of the decisions and deeds made by men in the theaters of war and politics. Few men troubled to devote such intelligent and detailed attention to this field, concerned as they were with the public affairs in which they played a direct part. Austen, however, developed a scrutiny so sensitive that it would be fair to call her work a micro-history (in Iain McCalman's sense), ${ }^{23}$ were it not for the fact that in delineating the manners and morals of the country gentry she not only puts on record what seemed too small to include in conventional history, but does so on a macro-scale. She examines the social construction of whole strata of England-the contemporary clergy, navy, and aristocracy - and offers analyses of communities as differ-

\footnotetext{
22 In addition to the studies already cited in notes 1, 2, and 3, see also Chris Jones, "Jane Austen and OId Corruption," Literature and History, 9, no. 2 (2000), 1-16.

${ }^{23}$ See Iain McCalman, Radical Underworld: Prophets, Revolutionaries, and Pornographers in London, 1795-1840 (Cambridge: Cambridge Univ. Press, 1988).
} 
ent as Portsmouth, Bath, and Pemberley. In effect she not only exhibits what Raymond Williams calls new structures of feeling (structures that are also, I would add, structures of thinking, speaking, and acting), but she also traces their generation from the inside outward. Her achievement is to transform the romantic story - the woman sighing for a soldier - into a discourse in which politics and history can be seen to begin at home.

In Pride and Prejudice Austen brings aristocratic corruption and military immorality home to the shires in the form of soldiers who, after the vast expansion of army and militia, were now living in villages and towns all over the country. And she did so at a time when, as Chris Jones reminds us, the York scandal led her friends and acquaintances to support the radicals' campaign for reform of the army and of parliament. ${ }^{24}$

The militia first appears in chapter 7 of the novel, and Austen's depiction of the officers is colored by their contemporary reputation for sexual dalliance. Catherine and Lydia Bennet are obsessed with the dazzling color of the military uniforms: "They could talk of nothing but officers; and Mr. Bingley's large fortune, the mention of which gave animation to their mother, was worthless in their eyes when opposed to the regimentals of an ensign." ${ }^{25}$ And Mrs. Bennet herself says: "I remember the time when I liked a red coat myself very well" (p. 29). From the start the soldiers are seen in terms of the romantic naiveté of the younger sisters and of the nostalgia of Mrs. Bennet, who has learned nothing from her greater experience.

Why is the militia seen in this way? Do the Bennet women's desires simply reflect their own silliness, or do they tell us something about the contemporary reputation of the militia? Austen's narratorial irony suggests that she wishes to play upon that reputation as well as satirize the Bennets, for in chapter 12 she has this to say about the soldiers:

Much had been done, and much had been said in the regiment since the preceding Wednesday; several of the officers had

24 See Jones, "Jane Austen and Old Corruption," pp. 2-3.

25 Jane Austen, Pride and Prejudice, vol. 2 of The Novels of Jane Austen, ed. R. W. Chapman, 3 d ed., 5 vols. (Oxford: Clarendon Press, 1965 ), p. 29 . Further quotations are from this edition and are included in the text. 
dined lately with their uncle, a private had been flogged, and it had actually been hinted that Colonel Forster was going to be married. (p. 6o)

Here Austen's free indirect speech ironizes Catherine's and Lydia's indiscriminate admiration of the troops even as it narrates it. The sentence shows military life to be a routine of trivial social engagements and gossip about affairs of the heart, but one in which brutal punishment seems just another amusing and ordinary event in the social round. The inclusion of the detail of the flogging shows the Bennet sisters'-and the militia'smoral sense to be sadly lacking. The sisters view the whipping of an ordinary soldier as an unremarkable detail, a scene appropriate to mention - so used are they to it - along with polite dinners and engagements.

It is worth remembering that the issue of flogging was topical in the years in which Austen was rewriting her novel. In 1809 William Cobbett had seized on a newspaper report in the Courier to launch a public attack on the government. On 24 June 1809 the Courier noted: "The Mutiny amongst the LOCAL MILITIA which broke out at Ely, was fortunately suppressed . . . by the arrival of four squadrons of the GERMAN LEGION CAVALRY. . . . Five of the ring-leaders were tried by a Court Martial, and sentenced to receive 5oo lashes each." 26 Horrified at the punishment and resentful that hired German troops had been used against Englishmen, Cobbett went on the attack in his radical paper Cobbett's Weekly Political Register, writing with heavy sarcasm: "Five hundred lashes each! Aye, that is right! Flog them; flog them; flog them! They deserve it, and a great deal more. They deserve a flogging at every meal-time. 'Lash them daily, lash them duly.' . . . O, yes; they merit a double-tailed cat. Base dogs!" He also imagined the impression that the affair made on the people of Ely: "I really should like to know how the inhabitants looked one another in the face, while this scene was exhibiting in their town." ${ }^{27}$ For Cobbett the

${ }^{26}$ The Courier, 24 June 1809 ; quoted in William Cobbett: Selected Writings, ed. Leonora Nattrass, 6 vols. (London: Pickering and Chatto, 1998), II, 249.

${ }_{27}$ Cobbett, "Summary of Politics," in Selected Writings, II, $249^{-} 5^{\text {o. The article first }}$ appeared on 1 July 1809 . 
affair revealed a corrupt ministry in action: having made the militiamen pay for their own knapsacks, while their officers dined in plenty, it used foreign troops to lash protesters into submission. The floggings were symbolic of a government that was all too similar to the despotic Napoleonic regime across the channel.

Cobbett's article became famous because the ministry used it to try to silence him, the radical pressman it feared most. The ministry prosecuted Cobbett for libeling the German troops, but this only protracted the publicity and gave him the chance to reiterate his charges at the trial. On 15 June 1810 , during his trial, Cobbett used the flogging to portray the whole militia system as both dangerous to English liberties and inefficient militarily:

If one of us was in a garrison town, and saw a soldier flogged to death ... would it be criminal to say any thing, or to write any thing, upon the subject? What! is every man who puts on a red coat, to be from that moment deserted by all the world; and is no tongue, or no pen, ever to stir in his defence? Who were these local militiamen? The greater part were then young fellows, probably in smock frocks, just taken from the plough, and ignorant of that subordination that is practised in the army. I allow that against a serious mutiny severe measures may be necessary; but then by mutiny, I understand taking up arms, and forcibly and violently resisting the officers in the execution of their military duties. I do not think a mere discontent and squabble in a corps ... should either receive the name or punishment of mutiny. I, and other people, told Lord Castlereagh from the beginning, that it would come to this; that these local militiamen would be made just soldiers enough to be disinclined to return to labour, and that they would be so much of labourers as never to be made effective soldiers. ${ }^{28}$

Cobbett was imprisoned after a Special Jury of middle-class men found him guilty. But he and others kept the militia in the public eye. In 1810 Leigh Hunt responded to Cobbett's trial by publishing a critique of military flogging in The Examiner. Ti-

${ }^{28}$ Cobbett, quoted in "Law Report. Court of King's Bench, Friday, June 15 ," in Selected Writings, II, 261. 
tled "One Thousand Lashes," the article lists horrific punishments for trivial offenses and reiterates Cobbett's charge that English militiamen were treated worse than Napoleon's soldiers:

Bonaparte does not treat his refractory troops in this manner: there is not a man in his ranks whose back is seamed with the lacerating cat-o'nine-tails:- his soldiers have never yet been drawn up to view one of their comrades stripped naked,- - his limbs tied with ropes to a triangular machine,- his back torn to the bone by the merciless cutting whipcord. . . they have never seen the blood oozing from his rent flesh. ${ }^{29}$

Publishing such inflammatory details got Hunt prosecuted too-but he was acquitted (despite the ministry packing the jury) when his defense lawyer, Henry Brougham, showed that flogging had "a direct and inevitable tendency to brutalize the people habituated to the practice of it." 30 Flogging was coming to seem not only cruel, but ineffective (as several serving generals argued in pamphlet publications). ${ }^{31} \mathrm{~A}$ brutalized army was a greater threat to British civilians than to Napoleon's unflogged troops.

What made flogging impinge on Austen's consciousness was its presence in the quiet English countryside. Hunt recorded dreadful whippings inflicted by militia officers in the Kentish towns among which Austen had lived: Canterbury, Chatham, Malling, and Bearstead. Sir Francis Burdett publicized still more incidents in 1811 and 1812 , demanding that flogging be abolished and attacking the barrack system and the

29 [Leigh Hunt], "One Thousand Lashes!!" The Examiner, 2 September 1810 , p. 557. Thanks to Michael Eberle Sinatra and Morton D. Paley for information on Hunt.

30 Brougham, speaking before the House of Commons, 6 March 1812, in Parliamentary Debates, 21 (1812), 1 204; quoted in J. R. Dinwiddy, "The Early NineteenthCentury Campaign against Flogging in the Army," English Historical Review, 97 (1982), $3^{25}$. As Dinwiddy shows (pp. 312-13), John Drakard, the editor who published the original story (which the Hunts reprinted), was not so fortunate: a packed jury at Lincoln convicted him and he was imprisoned for eighteen months.

31 See, for example, Lt.-Gen. John Money, A Letter to the Right Hon. William Windham, on the Defence of the Country at the Present Crisis (Norwich, 1806); Brig.-Gen. William Stewart, Outlines of a Plan for the General Reform of the British Land Forces, $2 \mathrm{~d}$ ed. (London, 1806); Lt.-Col. R. T. Wilson, An Enquiry into the Present State of the Military Force of the British Empire (London, 1804 ); all cited in Dinwiddy, "Flogging in the Army," p. $3^{10 .}$ 
use of the militia against civilians. His chief opponent was the Duke of York, recently reappointed as army commander, who, as J. R. Dinwiddy reports, "complained in 1826 that since "Liberalism and Philanthropy' had become the order of the day, there had been a great increase in the amount of military crime, especially insubordination" ("Flogging," p. 321 ).

With the reinstated York determined to whip soldiers into submission, the anti-flogging agitation became one strand of a larger campaign to reform the governmental system that could impose the rule of a corrupt, arbitrary, and callous aristocracy upon parliament, army, and people. Cobbett and his fellow radicals went on tour, attracting support from a scandalized country gentry that normally considered itself loyal to the King's ministers, of whichever party they were. At one Hampshire meeting a motion for reform proposed by Cobbett was signed by members of several families that featured in Austen's circle and that would not formerly have wished to be associated with the firebrand radical - the names included Portal, Powlett, and Mildmay. ${ }^{32}$ On the other side, among the Tory opponents of reform whom Cobbett attacked, were William Chute and Sir Thomas Heathcote-figures whom Austen mocked when they stood for parliament. ${ }^{33}$ Austen, in her letters and social connections at least, was on the side of those who saw flogging as an aristocratic abuse in need of change - and thus she, like many of the country gentry, was drawn to a cause that radicals and Whigs espoused as part of their attack on the Tory ministry.

In Pride and Prejudice Austen is neither Whig nor Tory, ${ }^{34}$ but she is a critic of the spread of aristocratic abuses into the gentry by means of the corrupting society of the militia. In other words, she is not a party writer-her fiction is concerned with tracing the social causes and effects of political decisions rather than with repeating the formulations of those causes and effects made in parliament. Austen is not formulaic but oblique,

32 See Jones, "Jane Austen and Old Corruption," pp. 2-3. See also Leigh Hunt's report of the meeting ("Hampshire Meeting," The Examiner, 30 April 1809, pp. 275-77).

s3 See Jones, "Jane Austen and Old Corruption," pp. 2-3; and Claire Tomalin, Jane Austen: A Life (New York: Alfred A. Knopf, 1997), p. 96.

34 This is not to say, of course, that Austen was unpolitical, but rather to remind ourselves that party discipline and party affiliations at this period were not fixed. 
yet she is nevertheless incisive in her deployment of current political and social anxieties in order to organize her readers' responses. In Pride and Prejudice the details of flogging and vanity, alluding to a contemporary public issue, have the effect of making readers wary of the militia. They anticipate Mr. Bennet's warning to Elizabeth: "Here are officers enough at Meryton to disappoint all the young ladies in the country. Let Wickham be your man. He is a pleasant fellow, and would jilt you creditably" (Pride and Prejudice, p. 138). Readers see first that militia officers are poor officers in terms of the latest military standards and are morally insensitive, and then they see that the officers are unreliable romantic partners who may exploit impressionable young women. Parliament's decision to raise ever-larger militias and station them across the countryside is registered not as a party issue but in terms of a dangerously seductive intrusion of a foreign body, with its own vain codes and loose standards, into the shires.

The details of the flogging at Meryton quietly cast doubt on Wickham's own statements because they make us suspicious of the kind of society offered by the militia-since Wickham joined up in order to enter that society. In chapter 16 he says to Elizabeth: "It was the prospect of constant society, and good society, . . . which was my chief inducement to enter the

shire. I knew it to be a most respectable, agreeable corps, and my friend Denny tempted me farther by his account of their present quarters, and the very great attentions and excellent acquaintance Meryton had procured them. Society, I own, is necessary to me" (p. 79). As readers we doubt Wickham, and the army that welcomes him, not just because of his blithe indifference to the very purpose of the militia (defending the country against the French), but also because of our already existing concern about the nature of the society that the militia offers. As we read between the lines and remember when (and in what national context) the novel is set, we see that Wickham and his fellow officers are characterized not by duty, discipline, or dedication to the country, but by social and romantic opportunism.

Austen shows, in effect, that political and social circumstances maketh the man (and woman): Wickham is not just a stereotypical romantic charmer but also, in his very desires and 
fears as well as his assumed attitudes, a specimen created by the social changes that the militia exemplifies. These social changes, in turn, are furthered by men such as Wickham, who are already the product of them. Austen's exact and discriminating understanding of her contemporary England amounts to more than a flair for detailing social nuances, since she constantly makes those nuances revelatory both of the interiority of individuals and groups and of the processes by which those individuals and groups change. What is decided in cabinet, debating chamber, and battlefield, Austen reveals, is the explicit form, the obvious surface of the shifting tensions, anxieties, and waysof-being that saturate the everyday.

It is the everyday social mobility offered by the new militia, the ability to escape one's past locale and reputation, that makes Wickham dangerous. After Darcy's letter exposes Wickham, Elizabeth reflects on how easily and casually he entered the militia: "She had never heard of him before his entrance into the - shire Militia, in which he had engaged at the persuasion of the young man, who, on meeting him accidentally in town, had there renewed a slight acquaintance" (pp. 205-6). Obscure to everyone, Wickham is all appearance; only when Elizabeth starts to get some information from Mrs. Gardiner's dim memories of his Derbyshire youth is she forced to question what lies beneath the polished manners and the sleek uniform. Elizabeth realizes that Wickham has flattered her by his polite exterior: what he comes to signify to her is her own vanity in being so easily pleased by his attentions. And his social mobility makes other officers, as well as Lydia, his dupes-when he elopes, it emerges that few in the militia know anything of his past, either. Even his commanding officer appears to lack the kind of knowledge necessary to judge him until it is too late: Colonel Forster is left looking in vain for information about an officer who has absconded - hardly a reassuring picture of military efficiency or of the judgment of men that was expected of a senior officer. The narrator relates the extent of Wickham's obscurity:

It was not known that Wickham had a single relation, with whom he kept up any connection, and it was certain that he had no near one living. His former acquaintance had been numerous; 
but since he had been in the militia, it did not appear that he was on terms of particular friendship with any of them. There was no one therefore who could be pointed out, as likely to give any news of him. And in the wretched state of his own finances, there was a very powerful motive for secrecy, in addition to his fear of discovery by Lydia's relations, for it had just transpired that he had left gaming debts behind him, to a very considerable amount. Colonel Forster believed that more than a thousand pounds would be necessary to clear his expences at Brighton. He owed a good deal in the town.... (pp. 297-98)

The anonymity and prestige conferred by the regimental uniform gave Wickham, literally and metaphorically, unwarranted credit - and his fellow soldiers and the townspeople were left to pay the price.

It is Darcy who clears up the resultant mess, stung into using the connections in Derbyshire and London that give him both knowledge of Wickham's past and power with regard to the present. Darcy and-as Austen suggests - the settled network of information and patronage controlled by the landed classes provide a reliable social order that, if used responsibly, is also a moral order. Darcy's fault hitherto has been that he has inherited a position in that network but has not lived up to the responsibility that this position confers on him. He has not met the obligation, recognized by eighteenth-century aristocrats as a justification of their inherited power, to use that power disinterestedly for the good. He has hoarded, but not used, the knowledge of Wickham that his position in the network provided him. By the end of the novel, however, he does use this knowledge, and Austen looks to Darcy and his fellow landowner Bingley, rather than to the new social order of the army, for a model of social and national government. A landowning class reminded of its responsibilities by interrelationships with the middle classes, rather than an army mimicking aristocratic manners (an army in which gentlemanliness is often no deeper than a shiny uniform), is the institution that Austen looks to for social stability.

The aristocratic vanity of the militia is symbolized throughout by its dress-sense - as a significant passage from the Meryton period reveals. Lydia remarks to Elizabeth: 
"Dear me! we had such a good piece of fun the other day at Colonel Forster's. . . We dressed up Chamberlayne ${ }^{35}$ in woman's clothes, on purpose to pass for a lady,- - only think what fun! Not a soul knew of it, but Col. and Mrs. Forster, and Kitty and me, except my aunt, for we were forced to borrow one of her gowns; and you cannot imagine how well he looked! When Denny, and Wickham, and Pratt, and two or three more of the men came in, they did not know him in the least. Lord! how I laughed! and so did Mrs. Forster. I thought I should have died. And that made the men suspect something, and then they soon found out what was the matter." (p. 221)

Here Austen tells readers several things at once. She shows Wickham's and his cronies' discernment to be very limited: they cannot see through the dress to the real person beneath, because they do not look with judgment or penetration. Perhaps Austen is telling us that, being as vain of their uniforms as Lydia is of her caps and gowns, the militia officers can no longer see what it is to be a man. The frivolity of the militia is on parade: Colonel Forster is playing charades rather than disciplining or leading his men, and the childish Lydia imposes her desires on the older commanding officer (a reversal of authority that will have disastrous consequences when Lydia is left under his care in Brighton). And Forster allows a feminization of the military: dressed in women's clothes, Chamberlayne symbolizes a militia in which soldiers act like girls, and girls have them under their command. Forster's game shows that the militia culture of vanity and display makes gentlemen forget their authority. Playing at soldiers turns to playing at dressing up, and lost in the process is the knowledge of how to playand be - a man. ${ }^{36}$ Austen effectively demonstrates the dangers

35 Chamberlayne, the tone suggests, may have been a servant rather than a militia officer-but the point here remains the militia's frivolity and lack of discernment. I am grateful to Jill Heydt-Stevenson for her suggestions concerning Austen's innuendos.

${ }^{36}$ Mary Wollstonecraft also makes this argument in A Vindication of the Rights of Woman (1792), where she sees the gambling and socializing of the soldiers as evidence of their corruption by the kind of vanity that, though usually associated with women, was dangerous in both sexes (see Wollstonecraft, A Vindication of the Rights of Woman, ed. Miriam Brody [Harmondsworth: Penguin, 1975], pp. 256-6o). 
of an aristocratic military culture of masquerade and display: in Pride and Prejudice, as in Mansfield Park (1814), dressing up and cross-dressing are signs of moral danger when the line between theater and reality is blurred (and as Roger Sales has shown, the Mansfield Park theatricals called for Henry Crawford to dress up as a soldier-performing a male part often played on the professional stage by a woman). ${ }^{37}$

The line gets further blurred at Brighton, where Forster loses command and Wickham compromises Lydia in order to get money from her relations. Wickham has tried to play this game before with Darcy's sister, but on that occasion Darcy's connections revealed the plot to him. Yet the mobility and anonymity - the alluring uniform and uniformity - offered by the militia, and by the militia as it functions in camp, let Wickham succeed the second time. Elizabeth greets the move to Brighton with what turns out to be unwitting prophetic irony: "Good Heaven! Brighton, and a whole campful of soldiers, to us, who have been overset already by one poor regiment of militia" (p. 220).

There had actually been a camp at Brighton in 1793 and 1795, featuring the militia defending the country against a mock invasion. Like the camp at Coxheath, it attracted fascinated sightseers and featured in newspapers and illustrations. According to the Morning Chronicle, "the firing of cannon and musquetry, and the immense crowds of spectators, were wonderfully pleasing. Every thing had the appearance of festivity and pleasure.... and displayed as gay and festive a sight, as can possibly be imagined." 38 Perhaps Austen read the newspaper reports, for Lydia looks forward to just such a party in the novel: "She saw all the glories of the camp; its tents stretched forth in beauteous uniformity of lines, crowded with the young and the gay, and dazzling with scarlet; and to complete the view, she saw herself seated beneath a tent, tenderly flirting with at least six officers at once" (Pride and Prejudice, p. 232). Like Coxheath, Brighton's bright color conceals a camp of immorality, indisci-

37 See Sales, Austen and Representations of Regency England, pp. $118-31,222-26$.
38 "Camp, near Brighton," Morning Chronicle, 26 August 1 793, p. [3]. 
pline, and show-one in which social and gender hierarchies are overturned and promiscuity is in the air. At the real Brighton Camp in 1795, the Times reported, the Prince of Wales patronized a masquerade that featured "a few lively Gentlemen in Petticoats, their Wives wearing the Breeches." ${ }^{39}$ Lydia's penchant for dressing militiamen up as women was, it seems, a trait founded on behavior at the real camp; Colonel Forster presides over the fictional one, and he fails to control either the men or the women in his charge: they are gambling and making love without his knowledge. Austen opposes Brighton Camp to Pemberley, where glittering surfaces are combined with depth: as Elizabeth discovers at Pemberley, order and tradition turn an appealing address into a place of virtue. Brighton Camp, by contrast, is a transitory place with no foundation: while Elizabeth is an enquiring visitor in Derbyshire, Lydia becomes a camp follower in Sussex. From there the road leads to the anonymous streets of that capital of social mobility and immorality, east London.

Yet it is clear that Lydia has learned nothing from her rash elopement to London. When she forces her sisters to hear the story of her wedding, she says of her "dear Wickham": "I longed to know whether he would be married in his blue coat" (p. 319).$^{40}$ To the end she is fascinated by the glittering surface that dress represents - which reminds us, by this stage of the novel, of the hollowness within. By this point Darcy has bought Wickham a place in the regular army, having saved Wickham's honor in the militia by paying his gambling debts to other officers. Darcy's actions let Wickham live a life of ease, able "to enjoy himself in London or Bath" (p. $3^{87}$ ), but they scarcely present the regular army in a good light; instead, it seems a useful social dumping ground for the plausible hypocrite who consults only his own pleasure. Once again the military gives Wickham social mobility: he goes to a regiment stationed in the north, where few people will know about the dishonor and embarrassment that surrounds him in Meryton and Derbyshire. And reg-

39 "Brighton, Oct. 1," London Times, 5 October 1 795, p. [3].

${ }^{40}$ This is probably a reference to the soldier wearing a civilian gentleman's clothes, and looking fine in them. 
iments in the north, in $1811-12$, were being used to crush the poverty-stricken, machine-breaking handloom weavers.

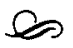

Jane Austen could discern the true character beneath the uniform, but, in the figures of Lydia, Wickham, and Forster, she showed her fear that many of her compatriots could not. In other words, she criticized the militia because, as an institution, it seduced too many of her fellow Britons, blurring the difference between true and fake gentlemanliness and giving greater scope than ever before for local vices and weaknesses to grow and move across the country. By spreading seductive surfaces across the land, the militia led many Britons to succumb to novelty and show, and to forget that the real man was known by the history of his deeds - small and large. And the militia, stationed at ease far from the action, had few chances to prove itself by deeds. The regular army, by contrast, did engage in battle, and it was a battle-hardened yet thoughtful regular soldier who came closest to fulfilling Austen's ideal of a true military character. Charles William Pasley was a veteran of war in the Mediterranean when, in 1811 , he published his Essay on the Military Policy and Institutions of the British Empire. In this work, which achieved considerable popular success, Pasley suggests that the nation's moral and political health would be improved by imperial conquest on land and sea. Pasley argues that conquest would revive Britain's manly vigor, and that the government's initial reluctance to colonize Malta was evidence of its effeminacy:

Thus, like the nursery maid, who stops the restless child in the midst of his play, by dreadful stories of some phantom that is coming to take him; we have often cramped ourselves in our operations, and have allowed ourselves to be terrified into inactivity, by our apprehension of drawing upon us the resentment of other nations; to which we ourselves ought to have dictated in a lofty tone, if they had presumed to speak one word in disapprobation of our measures. ${ }^{41}$

41 C. W. Pasley, An Essay on the Military Policy and Institutions of the British Empire, $2 \mathrm{~d}$ ed. (London: Edmund Lloyd, 1811 ), p. 176. 
A more masculine policy, for Pasley, would be more like that of the ancient Romans. He argues for a more "daring spirit" in pursuit of a land empire that would undermine Napoleon and make Britain dominant across Europe, as Rome had once been. Pasley talked tough and wrote in a terse, decisive, no-nonsense style, criticizing the aristocratic politesse that he thought governed the generals and politicians who made policy. For Pasley this politesse amounted to pusillanimity and effeminacy: what was needed instead was a forceful expression of what amounted to an empire of force. Britain had the men, guns, and resources to dominate Europe, and it should use them for "great conquests" rather than "paltry" gains, because the "warlike spirit, by which alone they can be effected, commands respect; and increasing power gradually changes the respect of other states into submission" (pp. 177-78). Pasley's stark message was conquer or be conquered, and he was sure that he had the answer for the previous "bad success of our armies": it was not from lack of valor among the men but from "want of a more daring spirit in our national councils," which preferred negotiation to aggression (p. 1 19). Essentially, Pasley wanted to turn international politics into single combat, for only then would nations act like men. Chivalry and policy alike were reduced to the image of a fighter squaring up to his opponent.

It seems surprising that Pasley should have impressed Jane Austen, who was normally so wittily wise about male pretensions. But impress her he did, although there are strong elements of irony in her judgment of him. ${ }^{42}$ She admired the selfconfident and terse masculinity of his style, preferring his compact book to the digressive travel writings that made up the stock of the neighboring subscribing library. In a 24 January 1813 letter to Cassandra, Austen declared Pasley's book "delightfully written \& highly entertaining" and, in a wittily sexualized comment, called its author "the first soldier I ever sighed for" (Letters, p. 292). In the process she redefined gentlemanly masculinity as a matter of manners and morals tested in (military) action, rather than as an imitation of the self-indulgence and vanity of the great aristocrats.

\footnotetext{
12 On Austen and Pasley, see Roberts, Austen and the French Revolution, p. 94.
} 
Pasley was no Wickham, and no York either, but instead a plain-writing man of action who redeemed the army from corruption, self-indulgence, and effeminacy. And he was neither an aristocrat nor an arrivist hiding his inexperience behind a red coat, but instead a man who had seen action. In admiring his masculinity (even if she did not comment on his politics), Austen suggested that imperial war was the arena in which the gentleman-via service in the regular army rather than the militia-could discover the manly authority that the nobility had surrendered, the authority necessary to govern effectively.

Pasley, his sphere of action outside Austen's direct experience, was confined to her letters rather than her fiction. In Pride and Prejudice, observing the army at home, Austen portrays no military hero. Only Colonel Fitzwilliam resists the corrupting influence of the militia of which he is part, showing himself to be a sensitive and moral professional gentleman. Yet even he lacks scope to prove his character: it is only when Wickham brings on a crisis that he gains a field on which he carries his politeness into disinterested and effective deeds. Until then, confined to a routine of wining, dining, chit chat (and flogging), their previous history obscure, the militia officers face no test that will allow their mettle to be judged.

As Gary Kelly has argued, through her unheroic officers Austen offered a satire on current trends within the aristocracy and gentry, a satire whose social conservatism did not prevent her from taking up issues that radical Whigs used to attack Tories. ${ }^{43}$ Like that other critic of those trends, the aristocrat and radical Whig Lord Byron, Austen looked at masculinity as it was increasingly lived out in the fashionable institutions of Regency Britain and made the "want [of] a hero" the basis of her critique of the spirit of the age. Yet in addition to that critique, she also at least sketched what a proper military man might look like. While Austen finds stature and stability in the great reformed aristocrat Darcy, in Fitzwilliam she looks forward to the kind of professional that the lesser gentry might become in the nineteenth century, if given a field of action. She was to define that new professional gentleman fully in the

13 See Kelly, Women, Writing and Revolution, p. 182. 
figure of Captain Wentworth in Persuasion-a man whose honor and self-knowledge, although once weak, become reformed and deepened by the trials and opportunities experienced during a career in the war. ${ }^{44}$ But Wentworth, like Pasley and like her own sailor brothers, is tested abroad; the militia stayed at home, an institution that in Austen's depiction epitomized the insular frivolity that threatened Britain's governors from within. In both Pride and Prejudice and Persuasion, then, Austen depicts British society as only semi-adequate to form the character of the nation's ruling class (and sex); instead, the renewal of the gentry must come from the hard school of engagement in action. In showing that such action will occur mostly on the farflung seas and shores of Britain's empire, Austen anticipates the imperialist novel of the later nineteenth century.

Nottingham Trent University

${ }^{44} \mathrm{I}$ argue this point more fully in my "Romanticizing the Empire: The Naval Heroes of Southey, Coleridge, Austen, and Marryat," Modern Language Quarterly, 60 (1999), 161-96. See also Roberts, Jane Austen and the French Revolution, pp. 104-5. 